Pesq. Vet. Bras. 36(12):1194-1202, dezembro 2016

DOI: $10.1590 / \mathrm{S} 0100-736 \mathrm{X} 2016001200010$

\title{
In vitro culture of somatic cells derived from ear tissue of collared peccary (Pecari tajacu Linnaeus, 1758) in medium with different requirements ${ }^{1}$
}

\author{
Magda L.T. Santos², Alana A. Borges², Luiza B. Queiroz Neta², Maria V.O. Santos², \\ Moacir F. Oliveira ${ }^{3}$, Alexandre R. Silva ${ }^{4}$ and Alexsandra F. Pereira ${ }^{2 *}$
}

\begin{abstract}
Santos M.L.T., Borges A.A., Queiroz Neta L.B., Santos M.V.O., Oliveira M.F., Silva A.R. \& Pereira A.F. 2016. In vitro culture of somatic cells derived from ear tissue of collared peccary (Pecari tajacu Linnaeus, 1758) in medium with different requirements. Pesquisa Veterinária Brasileira 36(12):1194-1202. Laboratório de Biotecnologia Animal, Universidade Federal Rural do Semi-Árido, BR-110 Km 47, Presidente Costa e Silva, Mossoró, RN 599625-900, Brazil. E-mail: alexsandra.pereira@ufersa.edu.br

The maintenance of metabolic activities during the in vitro culture of somatic cells of wild animals, especially collared peccary (Pecari tajacu), is an interesting step in conservation of these cells for the use in nuclear transfer. In this context, it is necessary to optimize the culture conditions of somatic cells by the establishment of appropriate supplementation to the media. Therefore, this study aimed to analyze the composition of the culture means of somatic cell derived from ear tissue of collared peccaries, evaluating concentrations of fetal bovine serum (FBS; $10 \%$ vs. 20\%) and epidermal growth factor (EGF; 5ng/mL $v s .10 \mathrm{ng} / \mathrm{mL}$ ). Tissues were submitted to primary culture and subcultures for 40 days and cells were analyzed for morphology, adhesion, subconfluence, and proliferative activity to develop the growth curve and to determine the population doubling time (PDT), viability, and functional/metabolic activity. No difference was observed between the concentrations of FBS for several parameters, except for viability [FBS10: 85.6\% vs. FBS20: 98.2\%], PDT [FBS10: $155.4 \mathrm{~h}$ vs. $77.2 \mathrm{~h}$ ], and functional/metabolic assay [FBS10: 0.57-0.55 vs. FBS20: 0.82-0.99 (D5-D7)]. For the EGF in culture, no difference was observed in the evaluated parameters. In all experiments, the growth curves were typical S-shape and the cells passed through a lag, logarithmic, and plateau phase. In conclusion, 20\% FBS is suitable for the recovery of somatic cells; nevertheless, EGF does not improve the quality of growing these cells. To our knowledge, this is the first study culturing somatic cells of collared peccaries.
\end{abstract}

INDEX TERMS: Somatic cells, collared peccary, Pecari tajacu, culture medium, wild animals, conservation, somatic tissue, protein source, mitotic factor.

RESUMO.- [Cultivo in vitro de células somáticas derivadas de tecido auricular de cateto (Pecari tajacu Linnaeus, 1758) em meio com diferentes requerimentos.] A manutenção das atividades metabólicas durante o culti-

\footnotetext{
${ }^{1}$ Received on May 29, 2016.

Accepted for publication on July 19, 2016.

${ }^{2}$ Laboratório de Biotecnologia Animal, Universidade Federal Rural do Semi-Árido (UFERSA), BR-110 Km 47, Presidente Costa e Silva, Mossoró, RN 599625-900, Brazil. *Corresponding author: alexsandra.pereira@ufersa.edu.br

${ }^{3}$ Laboratório de Morfofisiologia Animal Aplicada, UFERSA, BR-110, Km 47, Presidente Costa e Silva, Mossoró, RN 599625-900, Brazil.

${ }^{4}$ Laboratório de Conservação de Germoplasma Animal, UFERSA, BR110 Km 47, Presidente Costa e Silva, Mossoró, RN 599625-900, Brazil.
}

vo in vitro de células somáticas de animais silvestres, especialmente cateto (Pecari tajacu), é uma etapa interessante na conservação dessas células para o uso na transferência nuclear. Nesse contexto, é necessário aperfeiçoar as condições de cultivo de células somáticas pelo estabelecimento de suplementações apropriadas aos meios. Portanto, este estudo objetivou analisar a composição dos meios de cultivo de células somáticas derivadas de tecido auricular de catetos, avaliando concentrações de soro fetal bovino (SFB; $10 \%$ vs. $20 \%$ ) e fator de crescimento epidermal (EGF; $5 \mathrm{ng} /$ $\mathrm{mL}$ vs. $10 \mathrm{ng} / \mathrm{mL}$ ). Para tanto, tecidos foram submetidos ao cultivo primário e subcultivos por 40 dias e células foram analisadas por morfologia, adesão, subconfluência, e ativi- 
dade proliferativa pelo desenvolvimento da curva de crescimento e determinação do time de duplicação da população (PDT), viabilidade, e atividade funcional/metabólica. Nenhuma diferença foi observada entre as concentrações de SFB para os vários parâmetros, exceto para viabilidade [SFB10: 85,6\% vs. SFB20: 98,2\%], PDT [SFB10: 155,4 h vs. $77,2 \mathrm{~h}$ ], e atividade funcional/metabólica [SFB10: 0,570,55 vs. SFB2 0: 0,82-0,99 (D5-D7)]. Para o EGF em cultivo, nenhuma diferença foi observada nos parâmetros avaliados. Em todos os experimentos, as curvas de crescimento foram típicas de forma $\mathrm{S}$ e as células passaram por uma fase lag, logarítmica e platô. Em conclusão, 20\% de SFB é adequado para a recuperação de células somáticas; contudo, EGF não melhora a qualidade de crescimento dessas células. Ao nosso conhecimento, este é o primeiro estudo cultivando células somáticas de catetos.

TERMOS DE INDEXAÇÃO: Células somáticas, tecido auricular, catetos, Pecari tajacu, meio de cultivo, animais silvestres, conservação, tecido somático, fonte proteica, fator mitótico.

\section{INTRODUCTION}

The conservation of animal genetic resources is an interesting strategy for the preservation of biodiversity (Machado et al. 2016) and a sustainable development through the establishment of captivities (Piovezan et al. 2012). In this context, study of the collared peccary (Pecari tajacu Linnaeus, 1758), wild animals of ecological, commercial and scientific importance is included. These animals participate in the food chain of mammals; have meat of considered appraisal and international interest leather (Bodmer et al. 1990). Furthermore, they can be used as an experimental model for other wild animals, phylogenetically close (Altrichter et al. 2015, Keuroghlian et al. 2013, Keuroghlian et al. 2014).

Nevertheless, the population of collared peccary is critically decreasing in some natural biomes, as the Caatinga and Atlantic Forest (Desbiez et al. 2012). Therefore, the development of reproductive strategies is necessary for their preservation and optimization of the population. In general, these strategies involve the cryopreservation of gametes and embryos (Andrabi \& Mawxell 2007, León-Quinto et al. 2009). In collared peccary, studies related to the cryopreservation of semen (Castelo et al. 2010, Souza et al. 2016) and ovarian tissue (Lima et al. 2012) have already been developed. However, to have a complete genetic representative of the population biodiversity, it is necessary to also consider banks of somatic cells and tissues (Cetinkaya \& Arat 2011, Li et al. 2009, Liu et al. 2014, Machado et al. 2016).

The somatic cell bank has different applications, ranging from the preservation of the genetic material of the species, avoiding the total loss of biodiversity in individuals who died prior to the reproductive stage, use in somatic cell nuclear transfer, study of the species by the performance of the in vitro culture of cells and basic research (Folch et al. 2009, León-Quinto et al. 2011, Caputcu et al. 2013, Pereira et al. 2013, León-Quinto et al. 2014). Regardless of the purpose, the obtaining of a banking of somatic cells begins with the skin biopsy and in vitro culture of recovered cells.

The banking of cells is closely linked to cellular cultu- re conditions. In wild animals, the number of explants can be reduced because of the number of individuals per species; special attention is required for the composition of the culture medium (León-Quinto et al. 2011). Two factors are important as the protein source and growth factor that favor the rapid cell growth (Gibbs et al. 2000, Li \& Lu 2005, Goissis et al. 2007). In different somatic cell lines, medium supplementation with $10 \%$ of fetal bovine serum has been the most widely used protocol (Cetinkaya \& Arat 2011, Pereira et al. 2013); however, in order to improve the somatic cell growth, higher concentrations have been tested and set (León-Quinto et al. 2011). Moreover, to determine a possible further improvement to the cell culture and proliferation, the epidermal growth factor has also been used, which becomes possible after the establishment of its ideal concentration (Li \& Lu 2005).

Thus, this study aimed to analyze the composition of the culture means of somatic cell derived from ear tissue of collared peccaries, evaluating different concentrations of fetal bovine serum and epidermal growth factor. To our knowledge, this is the first in vitro study culturing somatic cells of collared peccaries. The work could therefore be useful for the rest of peccaries, resulting as a starting point to initiate the implementation of nuclear transfer in this species.

\section{MATERIALS AND METHODS}

Ethics and animals. The use and care of animal were approved by the Animal Ethics Committee of the Federal Rural University of Semiarid (CEUA/UFERSA, no.23091.001072/2015-92), in compliance with the Chico Mendes Institute for Biodiversity Conservation (ICMBio, no.48633-1). Eighteen animals, seven males and 11 females were used, obtained at the Centre for Wild Animals Multiplication (Fig.1) of Federal Rural University of Semiarid (CEMAS, UFERSA, no.1478912). The animals were selected according to their health and body parameters and within the same age group (3-6 months).

Chemicals, reagents, and media. All reagents used in vitro culture were from Sigma-Aldrich (St Louis, MO, USA) and the medium and solutions were obtained from Gibco-BRL (Carlsbad, CA, USA). When necessary, the $\mathrm{pH}$ was adjusted to 7.2-7.4 for all media and solutions. Media were filtered through $0.22 \mu \mathrm{m}$ system (Corning, NY, USA) prior to use.

Skin biopsy and experimental design. Ear tissues from collared peccaries were obtained from the CEMAS/UFERSA and transported to the laboratory in phosphate buffer saline (PBS) supplemented with antibiotic solution $(10,000 \mathrm{U} / \mathrm{mL}$ penicillin $\mathrm{G}$, $10,000 \mathrm{mg} / \mathrm{mL}$ streptomycin) at $37^{\circ} \mathrm{C}$ for $30 \mathrm{~min}$. In collared peccary management systems, their identification has been recorded by ear sections and these fragments were used for the experiments. Then, small tissue fragments $\left(9.0 \mathrm{~mm}^{3} ; 3 \times 3 \times 1 \mathrm{~mm}^{3}\right)$ were washed in $70 \%$ ethanol and Dulbecco's modified Eagle's medium (DMEM) added with sodium bicarbonate, penicillin G, streptomycin, and amphotericin B.

After that, all small pieces were distributed into two experiments. In the first experiment, we evaluated the optimal concentration of protein source using fetal bovine serum (FBS) for the primary culture and sequential subcultures. Culture medium was supplemented with $10 \%$ or $20 \%$ FBS (FBS10 or FBS20). In the second experiment, we evaluated the influence of epidermal growth factor (EGF) at the in vitro culture medium until the third passage using two concentrations, $5 \mathrm{ng} / \mathrm{mL}$ and $10 \mathrm{ng} / \mathrm{mL}$ (EGF5 and 
EGF10). In the second experiment, comparisons were performed among EGF5, EGF10, and the best group of the first experiment (EGF0). For both experiments, qualitative and quantitative parameters were evaluated: morphological characteristics and quality of the cell culture during the primary culture and subcultures, proliferating activity for the preparation of the cell growth curve and determination of population doubling time (PDT), viability by Trypan blue, and functional/metabolic activity measured by 3-[4,5-dimethyl-thiazol-2-yl]-2,5-diphenyltetrazolium bromide (MTT) assay.

Primary culture and subcultures preparations. Tissue fragments were cultured in DMEM added with sodium bicarbonate, penicillin $\mathrm{G}$, streptomycin, amphotericin B, and FBS and/or $\mathrm{EGF}$ at $38.5^{\circ} \mathrm{C}, 5 \% \mathrm{CO}_{2}$ in air, and $95 \%$ relative humidity. The culture medium was changed daily. The cells were harvested when they reached $70 \%$ subconfluence and were subcultured into petri dishes (Pereira et al. 2013) for 40 days of culture. The $70 \%$ subconfluence was defined when $70 \%$ of the petri dishes showed somatic cells.

Assessment of culture quality. The daily assessment of the cell culture from the onset until the subconfluence stage was performed under inverted microscope (Nikon TS100, Tokyo, Japan) and the following parameters were evaluated: morphology, number of attached explants, number of explants with subconfluence, day of all attached explants, number of explants with grown to suconfluence, day of subconfluence explants, subconfluence total time, cell concentration in first passage, and adhesion ability of fragments in comparison with fragments cultured in medium using albumin bovine serum (BSA) as control group. BSA was added to the culture medium without FBS at the concentrations of $0.5 \%$ or $1 \%$ and the number of adhered explants was measured on days $3,6,9,12,15,18$, and 20 .

Proliferative activity. Proliferative activity was quantified according to the determination of population doubling time (PDT), which was calculated as follows: skin cells on the third passage were seeded in four-well plates at cell density of $1.0 \times 10^{4}$ cells/ well for the determination of the PDT. Cells were trypsinized from two wells and counted at $24 \mathrm{~h}$ intervals for up to $168 \mathrm{~h}$ of culture. The mean cell counts were recorded every time and so cell growth curve was prepared (Costa et al. 2005). Finally, the PDT was calculated using the following formula (Roth 2006):

$\mathrm{PDT}=\mathrm{T} \ln 2 / \ln (\mathrm{Xe} / \mathrm{Xb})$,

PDT is the time of the culture (in hours), $\mathrm{T}$ is the incubation time,

$\mathrm{Xb}$ is the number of cells at the beginning of the time incubation, Xe is the number of cells at the end of the incubation time, and $\ln$ is Napierian logarithm.

Cell viability. The viability analysis was performed by cells stained with Trypan blue assay. For each animal, the viability test was performed in duplicate. Briefly, the cells were centrifuged and suspended in $1.0 \mathrm{~mL}$ of the medium; an aliquot of cells was stained with $0.4 \%$ Trypan blue (in PBS) in the ratio 1:40 and counted in a Neubauer chamber (Strober 2001). Viability was measured at the end of primary culture in all experiments. Additionally, in second experiment, cells were frozen (Urio et al. 2011, León-Quinto et al. 2014) and the viability was evaluated before and after freezing. Briefly, cells were frozen in a solution containing $10 \%$ of DMSO and $0.2 \mathrm{M}$ sucrose in culture medium, stored in cryovials, and cooled at $-1^{\circ} \mathrm{C} / \mathrm{min}$ down to $-80^{\circ} \mathrm{C}$ using Mr. Frosty ${ }^{\circledR}$ (Thermo Fisher Scientific, Waltham, USA). After, the cryovials were transferred to liquid $\mathrm{N}_{2}$ tanks. After two weeks, frozen cryovials were thawed by immersion in a water bath at $37^{\circ} \mathrm{C}$ for $3-4 \mathrm{~min}$. Subsequently, cellular content was subjected to two washes to remove the cryoprotectants; the first was performed using culture medium con- taining $0.2 \mathrm{M}$ sucrose at $4^{\circ} \mathrm{C}$ for $15 \mathrm{~min}$. After centrifugation, the second wash was conducted using only culture medium, maintained at $25^{\circ} \mathrm{C}$ for $15 \mathrm{~min}$. The cell pellet was suspended in $1.0 \mathrm{~mL}$ of culture medium and the viability evaluated.

MTT assay. To evaluate the functionality and integrity of the membrane and cell metabolism, MTT assay was performed according to Mosmann (1983) with adaptations. Then, a concentration of $5.0 \times 10^{4}$ cells $/ \mathrm{mL}$ was grown in a humid atmosphere of $5 \% \mathrm{CO}_{2}$ at $38.5^{\circ} \mathrm{C}$ in $35 \times 15 \mathrm{~mm}$ petri dishes. After $5-7$ days, $1.5 \mathrm{~mL}$ of the MTT solution ( $5 \mathrm{mg} / \mathrm{mL}$ in DMEM) was added and the petri dishes incubated for a period of $3 \mathrm{~h}$ at the same conditions. The MTT solution was then removed and $1.0 \mathrm{~mL}$ of DMSO was added for $5 \mathrm{~min}$ under light stirring to solubilize the MTT. After the total dissolution of formazan crystals, samples were read in spectrophotometer (Shimadzu ${ }^{\circledR}$ UV-mini-1240, Kyoto, Japan), using an absorbance wavelength of $595 \mathrm{~nm}$.

Data analyses. Results were expressed as mean \pm SEM. Ten and eight animals for the first and second experiment were used, respectively. The PDT assay and viability were performed in duplicate for each animal of each treatment. Moreover, before the analysis of the cell viability, data were transformed to Arcsin. All data were analyzed by ANOVA and post hoc analysis test (paired and unpaired t-test) using the StatView 5.0 (SAS Institute, Inc. Cary, NY, USA), considering a significance value of $\mathrm{P}<0.05$.

\section{RESULTS}

\section{Establishment of FBS concentration in culture medium of skin cells}

Table 1 summarizes the results obtained for the culture quality and PDT assay between FBS10 and FBS20. Thus, the efficiency of total number of attached explants on the culture was $100 \%$ in all the cases. No differences were observed in attachment or subconfluence rates between experimental groups $(\mathrm{P}>0.05)$. Additionally, epithelial-like and fibroblast-like cells migrated from tissues fragments 7.0 (7.27.4) days after explanting. As time passed, cells continued to proliferate and were subcultured when they reached $70 \%$ confluences on the $11^{\text {th }}(11.7-11.8)$ day. No difference was observed in the cell concentration after first passage (FBS10:4.4 $\pm 0.2 \times 10^{4} \mathrm{cel} / \mathrm{mL} v s$. FBS20: $5.1 \pm 0.3 \times 10^{4} \mathrm{cel} / \mathrm{mL}$, $\mathrm{P}>0.05)$. After two to three passages, the cells showed morphologically consistent as fibroblast with fusiform aspect and central oval nucleus. They were viable and grew well after some passages.

Nevertheless, the differences, detected between FBS10 and FBS20 samples, were observed for the PDT assay (Table 1), while in the same time, cells cultured in the presence of $20 \%$ of FBS showed a greater potential for further division as compared to those cultured with $10 \%$ of FBS. Thus, it was observed that the proliferative activity was higher after the addition of $20 \%$ of FBS to the medium and a significant difference $(\mathrm{P}=0.03)$ was demonstrated when compared to the FBS10 treatment (Table 1).

For the evaluation of the ability of cellular adhesion of FBS, skin samples were cultured in the presence of FBS $(10 \%$ or $20 \%)$ and BSA $(0.5 \%$ or $1.0 \%)$ as negative control. Thus, in all in vitro culture days, both FBS concentrations showed higher values of attached explants with cell growth around it from of D6 when compared those cells cultured in BSA (Table 2 ). On the ninth day of culture, all cells grown in the presence of FBS fragments remained attached, while those grown in 
the presence of BSA reduced their cell adhesion, obtaining the complete inhibition of adhesion on the $18^{\text {th }}$ and the $20^{\text {th }}$ days for the BSA concentrations of $0.5 \%$ and $1 \%$, respectively.

After the third passage, the cells were submitted to the growth profile analysis by duplication rate of the population (PDT) assay. The growth curve of both treatments was established with FBS addition in the medium; they had the typical form of an S (Fig.2 A). It was observed that the latency phase (lag phase) length was lagging about $48 \mathrm{~h}$. Then, the cells rapidly proliferated entering exponential growth (the log phase). The transition was achieved from log phase to stationary phase between 4-5 and 5-6 days of culture for FBS2 0 and FBS10, respectively. After this period, the population began to degenerate and enter the decline or death phase after the $6^{\text {th }}$ culture day for both treatments.

The Trypan blue viability assay and the functional/metabolic viability by MTT assay were employed for cultured cells (Fig.3A,B). A higher percentage of cell viability was observed in the treatment using $20 \%$ of FBS after primary culture cells when compared the cells cultured with $10 \%$ of FBS (Fig.3A, $\mathrm{P}=0.03$ ). The treatments showed $85.6 \%$ and $98.2 \%$ of cell viability for the FBS10 and FBS20 groups respectively.

In relation to the evaluation of metabolic/functional viability by MTT assay (Fig.3B), the results were expressed in absorbance (abs) and comparisons between groups were performed. After 5 and 7 days of culture, a greater metabolic activity was observed, 0.57 and 0.82 for cultures with $10 \%$ of FBS addition and 0.55 and 0.99 for cultures with $20 \%$ of FBS addition, for the respective days. In this analysis, a significant difference between the treatments was found; however, the results within treatments showed no difference $(\mathrm{P}>0.05)$.

\section{Influence of EGF during in vitro culture of skin cells}

For treatments with the addition of 0.5 , and $10 \mathrm{ng} /$ mL EGF, 31 initial explants were used per concentration. All grown explants obtained $100 \%$ (31) of attached samples on days 4.9, 7.0, and 3.5 of culture $(\mathrm{P}>0.05)$ for 0.5 , and $10 \mathrm{ng} / \mathrm{mL}$ EGF respectively. Analysis of subconfluence around the explants for all treatment showed 100\% (31) attached explants at the end of the primary culture. Therefore, no differences in attachment, subconfluence rates and PDT assay were observed among experimental groups (Table 3). Additionally, all primary cultures showed $70 \%$ subconfluence after 12.6 culture days. Regarding morphology, all cells showed the same aspect as shown in Experiment 1, without influence of EGF (Fig.4A-F).

After establishing the growth curve for the different supplementations in culture (EGF, EGF5, or EGF10), all cells showed typical behavior in the form of S (Fig. 2 B). All cells showed the lag phase and the exponential growth (the log phase) presented a duration time of about $48 \mathrm{~h}$ and all treatments showed no significant difference between them $(\mathrm{P}>$ $0.05)$. The transition from log to stationary phase was achieved between 5-6, 6-7, and 6-7 days of culture for EGF0, EGF5, and EGF10, respectively. After this period, the population began to degenerate and enter the decline or death phase after the $6^{\text {th }}$ day of culture for all concentrations.

Table 1. Effect of fetal bovine serum (FBS) concentration on the ability of ear skin samples from collared peccaries in vitro cultured by 40 days

\begin{tabular}{|c|c|c|c|c|c|c|c|}
\hline \multirow[t]{2}{*}{ FBS } & \multicolumn{4}{|c|}{ No of explants } & \multicolumn{2}{|c|}{ No of attached explants } & \multirow[t]{2}{*}{$\mathrm{PDT} \pm \mathrm{SEM}(\mathrm{h})$} \\
\hline & Initial & $\begin{array}{l}\text { Attached } \\
(\%)\end{array}$ & $\begin{array}{l}\text { Day all attached } \\
\text { explants } \pm \text { SEM }\end{array}$ & $\begin{array}{c}\text { Grown to } \\
\text { subconfluence (\%) }\end{array}$ & $\begin{array}{l}\text { Day all cell grow } \\
\text { explants } \pm \text { SEM }\end{array}$ & $\begin{array}{l}\text { Subconfluence total } \\
\text { time (days) } \pm \text { SEM }\end{array}$ & \\
\hline FBS10 & 39 & $39(100)$ & $3.5 \pm 0.3$ & 39 (100) & $7.4 \pm 0.4$ & $11.8 \pm 0.6$ & $155.4 \pm 29.9^{a}$ \\
\hline FBS20 & 35 & $35(100)$ & $3.0 \pm 0.5$ & $35(100)$ & $7.2 \pm 0.5$ & $11.7 \pm 0.7$ & $77.2 \pm 2.1^{\mathrm{b}}$ \\
\hline
\end{tabular}

$\overline{\mathrm{a}, \mathrm{b}}$ In same column differ $(\mathrm{P}<0.05)$.

Table 2. Effect of fetal bovine serum (FBS) concentration on the adhesion of ear skin cells from collared peccaries in vitro cultured

\begin{tabular}{|c|c|c|c|c|c|c|c|c|c|}
\hline \multirow{2}{*}{$\begin{array}{l}\text { Protein } \\
\text { source }\end{array}$} & \multirow[t]{2}{*}{ [] in \% } & \multicolumn{8}{|c|}{ Samples } \\
\hline & & Initial & $\begin{array}{c}\text { Attached } \\
\text { D3 (\%) }\end{array}$ & $\begin{array}{c}\text { Attached } \\
\text { D6 (\%) }\end{array}$ & $\begin{array}{l}\text { Attached } \\
\text { D9 (\%) }\end{array}$ & $\begin{array}{l}\text { Attached } \\
\text { D12 (\%) }\end{array}$ & $\begin{array}{l}\text { Attached } \\
\text { D15 (\%) }\end{array}$ & $\begin{array}{l}\text { Attached } \\
\text { D18 (\%) }\end{array}$ & $\begin{array}{l}\text { Attached } \\
\text { D20 (\%) }\end{array}$ \\
\hline \multirow[t]{2}{*}{ FBS } & 10 & 39 & $18(46.1)^{\mathrm{ac}}$ & $37(94.9)^{\mathrm{a}}$ & $39(100.0)^{a}$ & $39(100.0)^{a}$ & $39(100.0)^{a}$ & $39(100.0)^{a}$ & $39(100.0)^{a}$ \\
\hline & 20 & 35 & $25(71.4)^{\mathrm{a}}$ & $34(97.1)^{a}$ & $35(100.0)^{\mathrm{a}}$ & $35(100.0)^{\mathrm{a}}$ & $35(100.0)^{\mathrm{a}}$ & $35(100.0)^{\mathrm{a}}$ & $35(100.0)^{\mathrm{a}}$ \\
\hline \multirow[t]{2}{*}{ BSA } & 0.5 & 35 & $12(34.3)^{\mathrm{bc}}$ & $17(48.6)^{\mathrm{b}}$ & $15(42.9)^{\mathrm{b}}$ & $10(28.6)^{b}$ & $7(20.0)^{\mathrm{b}}$ & $0(0.0)^{\mathrm{b}}$ & $0(0.0)^{\mathrm{b}}$ \\
\hline & 1.0 & 40 & $10(25.0)^{\mathrm{bc}}$ & $15(37.5)^{\mathrm{b}}$ & $8(20.0)^{b}$ & $11(27.5)^{b}$ & $3(7.5)^{b}$ & $3(7.5)^{b}$ & $0(0.0)^{\mathrm{b}}$ \\
\hline
\end{tabular}

$\overline{\mathrm{a}, \mathrm{b}, \mathrm{c}}$ In same column differ $(\mathrm{P}<0.05)$. Attached samples = number of explants with detachment or cell growth around them in their day.

Table 3. Effect of epidermal growth factor (EGF) concentration on the ability of ear skin samples from collared peccaries in vitro cultured by $\mathbf{4 0}$ days

\begin{tabular}{|c|c|c|c|c|c|c|c|}
\hline \multirow{2}{*}{$\begin{array}{l}\text { EGF } \\
(\mathrm{ng} / \mathrm{mL})\end{array}$} & \multicolumn{4}{|c|}{ No of explants } & \multicolumn{2}{|c|}{ No of attached explants } & \multirow[t]{2}{*}{$\mathrm{PDT} \pm \mathrm{SEM}(\mathrm{h})$} \\
\hline & Initial & Attached (\%) & $\begin{array}{l}\text { Day all attached } \\
\text { explants } \pm \text { SEM }\end{array}$ & $\begin{array}{c}\text { Grown to } \\
\text { subconfluence (\%) }\end{array}$ & $\begin{array}{l}\text { Day all cell grow } \\
\text { explants } \pm \text { SEM }\end{array}$ & $\begin{array}{l}\text { Subconfluence total } \\
\text { time (days) } \pm \text { SEM }\end{array}$ & \\
\hline EGF0 & 31 & $31(100)$ & $4.9 \pm 0.9$ & $31(100)$ & $7.2 \pm 0.7$ & $12.6 \pm 0.2$ & $69.6 \pm 5.5$ \\
\hline EGF5 & 31 & $31(100)$ & $7.0 \pm 1.8$ & $31(100)$ & $8.2 \pm 0.8$ & $12.6 \pm 0.2$ & $64.8 \pm 4.0$ \\
\hline EGF10 & 31 & $31(100)$ & $3.5 \pm 0.9$ & $31(100)$ & $7.9 \pm 0.6$ & $12.6 \pm 0.2$ & $65.8 \pm 5.8$ \\
\hline
\end{tabular}

No difference in same column $(\mathrm{P}>0.05)$. 
After the cell trypsinization, no difference was observed among the all groups for viability by Trypan blue assay (EGF0: 84.3\% vs. EGF5: 88.8\% vs. EGF10: 87.1\%; Fig.3C). After 5 and 7 days of culture (Fig.3D), no difference was also observed for metabolic activity among groups for D5 (EGF0: 1.26 vs. EGF5: 1.13 vs. EGF10: 1.14) and D7 (EGF0: 1.06 vs. EGF5: 1.38 vs. EGF10: 1.16). Additionally, a viability by Trypan blue and concentration were evaluated in cells after even passage, before and after cryopreservation (Table 4). No significant difference was observed among treatments, confirming that the EGF had no effect on cell viability at each passage and after cryopreservation.

\section{DISCUSSION}

The addition of serum to the culture media has an important significance on cell growth, supporting the cells as a protein and growth factors source, as well as providing cell adhesion and expansion through factors, as collagen and fibronectin (Hosokawa et al. 1997). The addition of $10 \%$ of serum has been the most widely used for fibroblasts culture establishment in different species (Han et al. 2003, Caamaño et al. 2008, Liu et al. 2010, Bai et al. 2012). Nevertheless, in order to enhance cells culture of skin cells deriving from collared peccary, in this study the addition

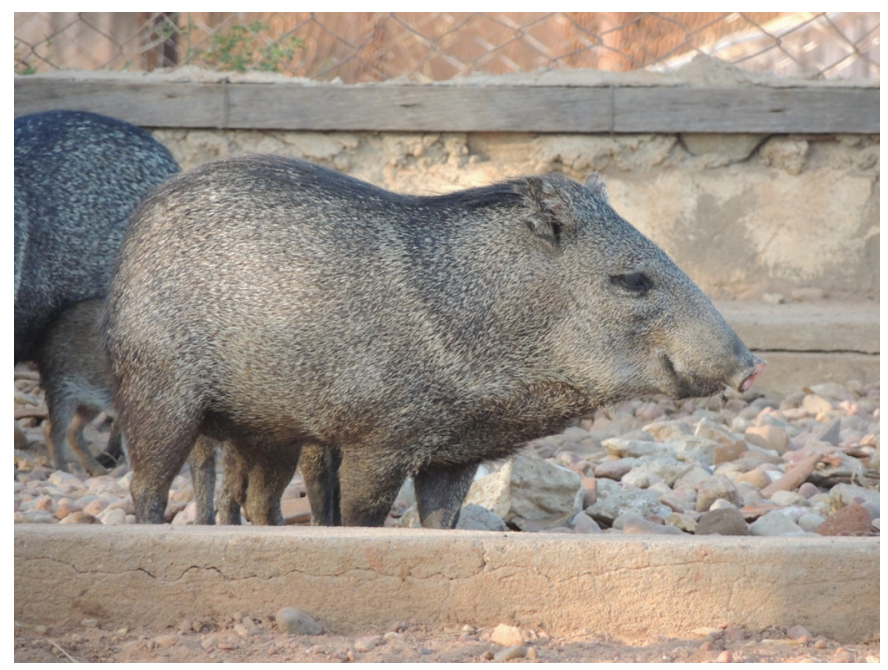

Fig.1. Collared peccary preserved in the Centre for Wild Animals Multiplication of Federal Rural University of Semiarid (No.1478912).

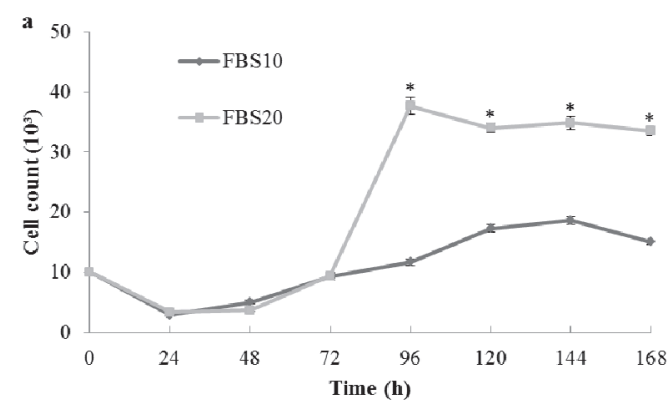

of $20 \%$ of FBS was also used to the culture medium, since for some species, this percentage may vary for the same cell type (León-Quinto et al. 2011). Moreover, in swine, domestic species phylogenetically nearest to the collared peccary, the serum concentration also varied between $10 \%$ and 20\% (Silvestre et al. 2002, Silvestre et al. 2003, Shi et al. 2015). Additionally, a serum concentration greater than $10 \%$ may be useful in situations where the number of fragments is reduced. On endangered wild species, the number of fragments and their size are important factors that can be solved with culture media with high ability for cell growth (León-Quinto et al. 2011)

For both FBS concentrations tested in the culture, we have obtained a maximum number of attached explants and maximum subconfluence around them, possibly due to the favorable conditions in the culture medium. In swine skin cells, explants cultured in $20 \%$ of SFB also showed $100 \%$ of attached samples after 7-14 days of culture; however, only $88 \%$ attached samples were observed with the growth to subconfluence evaluated up to 28 days of culture (Silvestre et al. 2002). Moreover, we observed that the addition of $20 \%$ of serum caused greater cell proliferation in the early days of culture, since a significant increase was observed in the number of cells after primary culture. In FBS composition, these are commonly found: transportation, adhesion proteins and enzymes, hormones, growth factors, cytokines, fatty acids, lipids, vitamins, carbohydrates, and nitrogen nonprotein source (Brunner et al. 2010) and a larger amount of these substances favor greater cell proliferative activity.

To evaluate the extent to which FBS influences the cell adhesion, the number of explants that presented the detachment or the cell growth around it was quantified for each day and compared to the BSA, a negative control commonly used in embryo culture systems and gametes in two different concentrations. The BSA is added to the medium as a protein source, since it is widely used in the oocytes and embryos culture and maintenance (Evecen et al. 2004) and is also present in the composition of some synthetic media for the culture of adherent somatic cells (Kan \& Yamane 1982) and cells grown in suspension (Magalhães et al. 2012). Nevertheless, it inhibits cell adhesion, requiring the addition of adhesion factors, as fibronectin (Kan \& Yamane 1982).

It was observed that the explants continued adhered du-

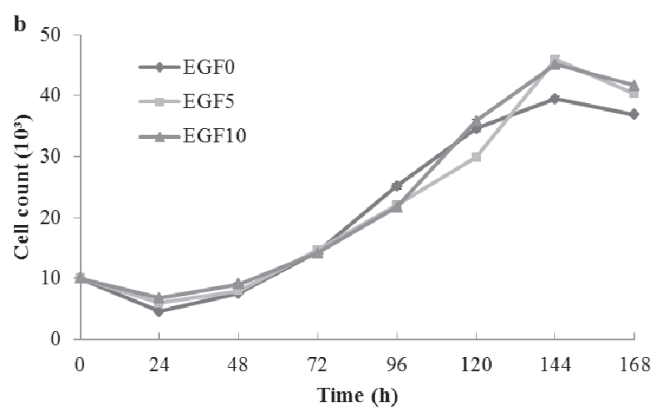

Fig.2. The growth curve of skin cells derived from somatic tissue of collared peccary and cultured in medium supplemented with (A) FBS and (B) EGF. * Differ for same time in different groups $(\mathrm{P}<0.05)$. 
ring the first 6 days of culture, suggesting that the washings carried out in medium containing FBS prior to fixation could be related to this behavior. Furthermore, these observations may also be linked to the growth and adhesion factors that are still present in the explant. However, after 6 days of culture, the percentage of explants with detachment around the explant decreased until it reached $0 \%$, confirming the inhibition of adhesion when using only BSA.

Regarding the assessments carried out for the subcultures, it was possible to confirm the high performance of culture with the addition of $20 \%$ of FBS to the medium when compared to treatment with $10 \%$ of FBS. Since after the third passage of cells were subjected to analysis of their growth profile or PDT assay and the values for treatment with addition of $20 \%$ of FBS were significantly greater. It was observed for both curves that the lag phase duration was about $48 \mathrm{~h}$. This characteristic is similar to the culture of the same cell type in other species using DMEM culture medium with $10 \%$ of FBS (Na et al. 2010, Bai et al. 2012). In this lag phase, the duration was lower than the one found by Li et al. (2009) in bovine cultured fibroblasts. Both treatments showed satisfactory latency periods, since this period is required for cell recovery after mechanical damage and exposure to trypsin.

For the cell viability in different cultures, other study aimed at establishing fibroblasts derived from ear tissue in cattle (Li et al. 2009) using as culture medium, DMEM, plus $10 \%$ of FBS and achieved a well higher viability rate, 97.6\%. Equivalent results were found in Wuzhishan miniature pig, $97.8 \%$ in the same growing conditions (Liu et al. 2014). This suggests a greater reliance for FBS in the culture medium in the case of cells derived from ear tissue of peccaries in relation to their cell viability maintenance because equivalent results were achieved in our study only with the addition of $20 \%$ of FBS to the culture medium. Moreover, the behavior exhibited by the collared peccary skin cells approached the behavior of Lynx pardinus fibroblasts (León-Quinto et al. 2011). In this study, the optimal culture tested when related to FBS concentration of $15 \%$ and did not differ from the result achieved with the addition of $20 \%$ of FBS to the medium containing the same cells.

In relation to the functional/metabolic viability MTT assay, the results were consistent with the data provided by the Trypan blue viability assay and the growth curve and these results allow relating metabolic activity with cell concentration. Since after 7 days of culture for both treatments metabolic/functional viability no significant difference was observed compared to day 5 of culture, indicating persistence of metabolic activity and integrity of the cells after 7 days of culture. These characteristics were also observed by Cetinkaya \& Arat (2011) using fibroblasts derived from bovine ear cartilage grown in DMEM with $20 \%$ of FBS. Studies of the property of skin cells have differences in their behavior, as the growth curve in the days of culture under
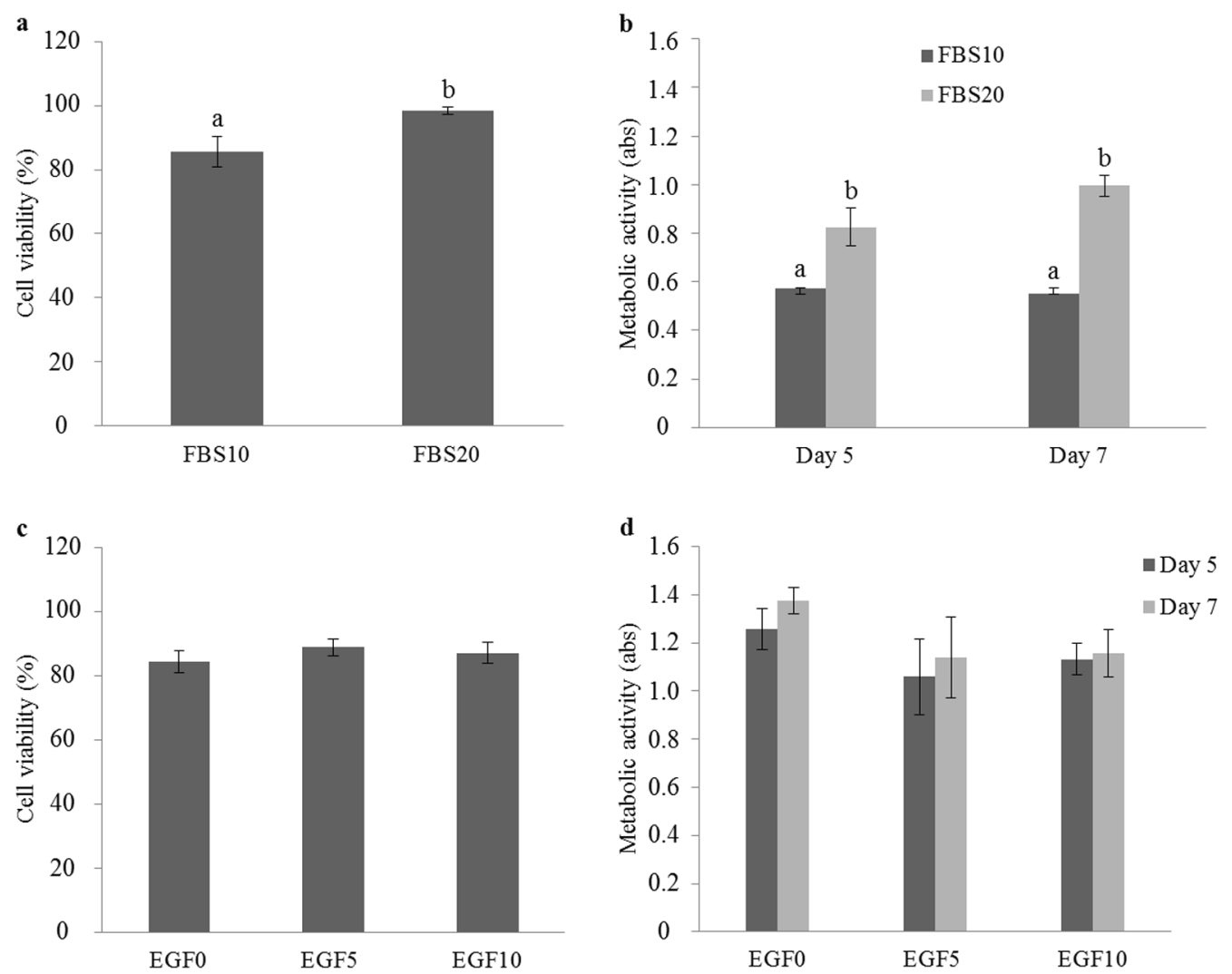

Fig.3. Assessment of viability by Trypan blue and metabolic functional by MTT assay. (A) Cell viability after the primary culture of treatments using FBS; (B) metabolic activity assessed by MTT assay after the third passage of treatments using FBS; (C) cell viability after the primary culture of treatments using EGF; (D) metabolic activity assessed by MTT assay after the third passage using EGF; $\mathrm{a}, \mathrm{b}=\operatorname{differ}(\mathrm{P}<0.05)$. 


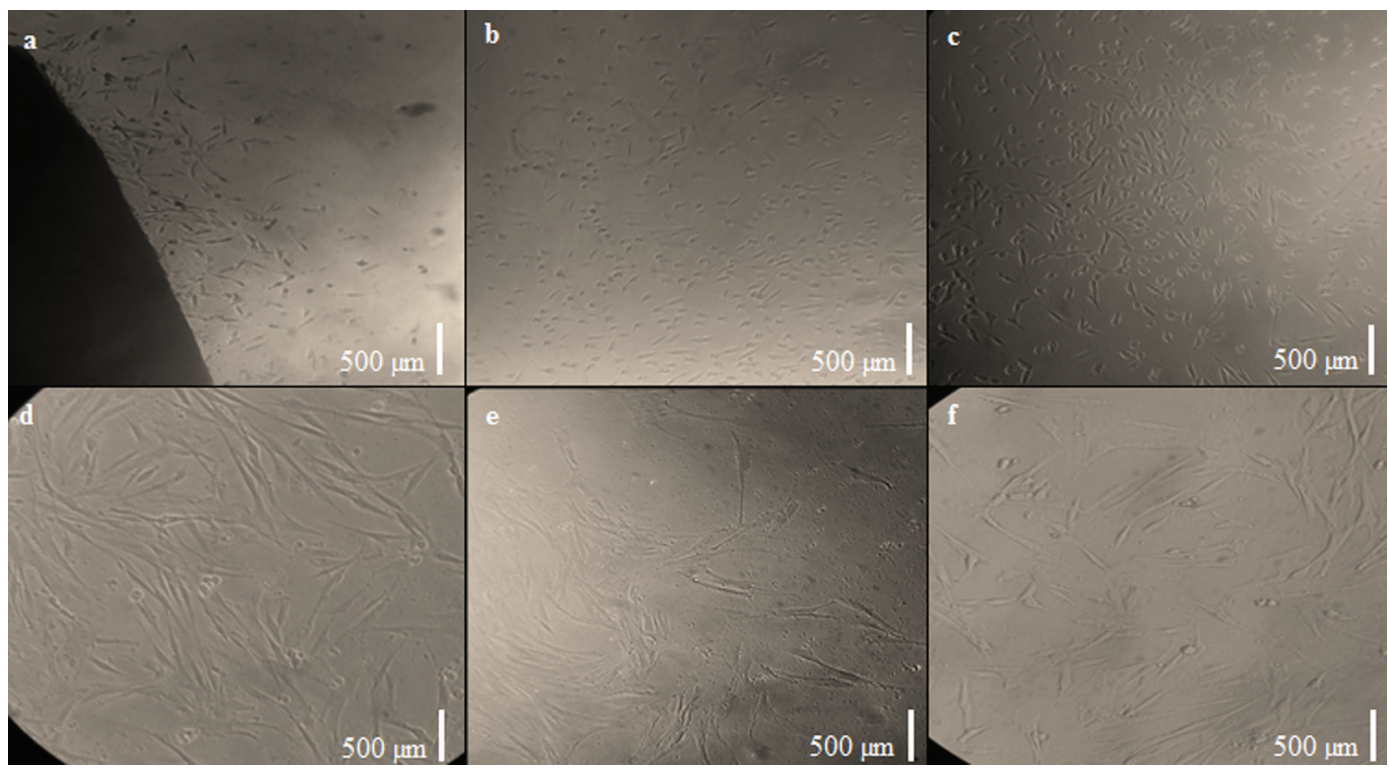

Fig.4. In vitro culture of ear tissue collared peccaries demonstrating the morphology, adhesion, and proliferation of cells. Primary culture: (A) early detachment and cell growth without addition of EGF; (B) early detachment and cell growth with addition of 5ng/mL of EGF; (C) early detachment and cell growth with addition of 10ng/mL of EGF. Subculture: (D) culture secondary and subconfluence without addition of EGF; (E) culture secondary and subconfluence with addition of 5ng/mL of EGF; (F) culture secondary and subconfluence with addition of $10 \mathrm{ng} / \mathrm{mL}$ of EGF. Scale bar: A-F $500 \mu \mathrm{m}$.

Table 4. Viability by Trypan blue assay after each passage and before and after cryopreservation in skin cells from derived somatic tissue of collared peccary and culture in the EGF presence

\begin{tabular}{|c|c|c|c|c|c|c|c|c|c|}
\hline \multirow[t]{3}{*}{ EGF } & \multicolumn{7}{|c|}{ Before of the cell cryopreservation (Mean \pm SEM) } & \multirow{2}{*}{\multicolumn{2}{|c|}{$\begin{array}{l}\text { After the cell cryopreservation } \\
\qquad(\text { Mean } \pm \text { SEM) }\end{array}$}} \\
\hline & \multicolumn{2}{|c|}{ First passage } & \multicolumn{2}{|c|}{ Second passage } & \multicolumn{3}{|c|}{ Third passage } & & \\
\hline & $\begin{array}{l}\text { Viability } \\
\text { (\%) }\end{array}$ & $\begin{array}{c}\text { Concentration } \\
\left(10^{4} \mathrm{cel} / \mathrm{mL}\right)\end{array}$ & $\begin{array}{l}\text { Viability } \\
(\%)\end{array}$ & $\begin{array}{c}\text { Concentration } \\
\left(10^{4} \mathrm{cel} / \mathrm{mL}\right)\end{array}$ & $\begin{array}{l}\text { Viability } \\
(\%)\end{array}$ & $\begin{array}{l}\text { Concentration } \\
\left(10^{4} \mathrm{cel} / \mathrm{mL}\right)\end{array}$ & $\begin{array}{c}\text { Viability before } \\
\text { cryopreservation (\%) }\end{array}$ & $\begin{array}{c}\text { Viability } \\
(\%)\end{array}$ & $\begin{array}{c}\text { Relative } \\
\text { viability (\%) }\end{array}$ \\
\hline EGF0 & $84.3 \pm 3.3$ & $7.8 \pm 1.5$ & $87.9 \pm 1.5$ & $32.3 \pm 2.5$ & $89.4 \pm 1.4$ & $20.0 \pm 1.4$ & $84.5 \pm 2.5$ & $61.2 \pm 2.4$ & $72.4 \pm 2.1$ \\
\hline EGF5 & $88.8 \pm 2.8$ & $6.3 \pm 1.0$ & $84.1 \pm 1.7$ & $28.1 \pm 5.4$ & $88.7 \pm 2.0$ & $17.7 \pm 2.5$ & $86.9 \pm 0.8$ & $61.0 \pm 3.0$ & $70.3 \pm 3.6$ \\
\hline EGF10 & $87.0 \pm 3.1$ & $8.8 \pm 0.8$ & $85.7 \pm 2.3$ & $36.5 \pm 5.1$ & $90.7 \pm 1.2$ & $23.4 \pm 3.3$ & $88.1 \pm 1.9$ & $55.2 \pm 3.1$ & $62.9 \pm 4.2$ \\
\hline
\end{tabular}

No difference in same column $(\mathrm{P}>0.05)$.

similar culture conditions. In cases of cooled tissue curve, cells reached the stationary phase on day 7 of culture as observed by Singh et al. (2011) and Singh \& Xiaoling (2014). Nevertheless, Mahesh et al. (2012) observed the same culture conditions at the beginning of the stationary phase on day 4 of the curve. Furthermore, it was observed that the cells were already in the decline phase in the curve in day 7 (Liu et al. 2011). Therefore, the evaluation of the MTT in days 5 and 7 of culture was proposed to determine the maximum proliferative and metabolic activity of the collared peccary skin cells in our conditions.

With the aim to try an additional positive effect on the already high performance obtained for the cell culture in the presence of $20 \%$ of FBS, we add the EGF mitogenic agent at 5 or $10 \mathrm{ng} / \mathrm{mL}$. However, the fact this supplementation did not present any difference in relation to the parameters evaluated for the initial culture, compared to EGF0, we evaluated the subcultures in more detail. For this reason, the viability by Trypan blue assay in cell freezing and determining the cell concentration was performed for every subculture. Still it did not demonstrate any difference compared to the addition of EGF to 5 or $10 \mathrm{ng} / \mathrm{mL}$. In addition, cryopreservation as a method of analysis can be applied, comparing the possible damage caused by this process (Cetinkaya \& Arat 2011). This behavior is related to the fact that epithelial tissue consists overall of about $80 \%$ keratinocytes. Since these cells have good response to EGF due to the large number of receptors epidermal growth factor receptor (EGFr). EGFr is directly related to various functions in this cell type, it is important for autocrine growth in tissue renewal, to promote cell survival, and cell migration regulation (Hudson \& McCawley 1998). Accordingly, the study on the epithelium of the ear tissue of collared peccary is necessary to determine more specific mitotic agents. For the explant culture of the ear tissue of $L$. pardinus studied by León-Quinto et al. (2011), the EGF had a beneficial effect.

Therefore, we believe that during the course of subculturing, the number of epithelial cells has decreased, being composed predominantly of fibroblasts and this greater amount of fibroblast cells may have caused the noninterference of EGF added to the culture medium. It is explained by the fact that the cells are mixed during the primary culture, which can grow in both group and dispersed (Guan et al. 2005). However, fibroblasts give off more rapidly from the petri dishes after addition of trypsin, may be removed 
while the epithelial cells are still adhered, brought about in obtaining a uniform culture (Liu et al. 2008, Wu et al. 2008). Also, probably, the treatment containing only $20 \%$ of FBS provided a similar response when compared to treatments with EGF because the presence of $20 \%$ of FBS has a satisfactory amount of this factor in the serum composition.

Moreover, comparing the values in Experiments 1 and 2 regarding the addition of only $20 \%$ of FBS to the culture medium, we observed a good reproducibility of in vitro culture because the values were very close for all analyzes. Additionally, the variation of animals from 3 to 6 months of age and gender did not affect the reproducibility of the data on analysis conditions and tested.

In conclusion, $20 \%$ of FBS is suitable for the recovery of somatic cells and shown to be effective for the growth and proliferation of skin cells for 40 days and until the fourth passage. However, EGF does not improve the quality of these growing cells, having no influence on the proliferative activity of the cells in the tested concentrations. To our knowledge, this is the first in vitro study culturing somatic cells of collared peccaries and it could be useful for the rest of peccaries, aiming the implementation of nuclear transfer.

Acknowledgements.- This study was supported by National Counsel of Technological and Scientific Development (CNPq) and Coordination for the Improvement of Higher Education Personnel (CAPES). The authors thank the Centre for Wild Animals Multiplication (CEMAS/UFERSA) for providing the animals, the Laboratory Gonadal Transplantation and In Vitro Embryo Production (LTG-PIV/UFERSA) and the Laboratory Biochemistry and Molecular Biology (BIOMOL/UERN) for technical assistance.

\section{REFERENCES}

Altrichter M., Taber A., Noss A., Maffei L. \& Campo J. 2015. Catagonus wagneri. The IUCN Red list of threatened species: e.T4015A72587993. $<$ http://dx.doi.org/10.2305/IUCN.UK.2015-2.RLTS.T4015A72587993. en> Accessed Nov. 7, 2015.

Andrabi S.M.H. \& Maxwell W.M.C. 2007. A review on reproductive biotechnologies for conservation of endangered mammalian species. Anim. Reprod. Sci. 99:223-243.

Bai C., Wang D., Su X., Zhang M., Guan W. \& Ma Y. 2012. Establishment and biological research of the Jining Grey goat fibroblast line. Turk. J. Vet. Anim. Sci. 36:659-667.

Bodmer R.E., Bendayan N.Y., Moya L. \& Fang T.G. 1990. Manejo de ungulados en la Amazonia Peruana: Analisis de su caza y commercializacion. Boln de Lima 70:49-56.

Brunner D., Frank J., Appl H., Dchöff H., Pfaller W. \& Gstraunthaler G. 2010 Serum-free cell culture: The serum-free media interactive online database. Altex 27:54-62.

Caamaño J.N., Rodriguez A., Salas A., Munoz M., Diez C., Prather R.S. \& Gomez E. 2008. Flow cytometric cell cycle analysis of cultured brown bear fibroblast cells. Cell Biol. Int. 32:855-859.

Caputcu A.T., Akkoc T., Cetinkaya G. \& Arat S. 2013. Tissue cryobanking for conservation programs: effect the tissue type and storage time after death. Cell Tissue Bank 14:1-10.

Castelo T.S., Bezerra F.S.B., Souza A.L.P., Moreira M.A., Paula V.V., Oliveira M.F. \& Silva A.R. 2010. Influence of the thawing rate on the cryopreservation of semen from collared peccaries (Tayassu tajacu) using Trisbased extenders. Theriogenology 74:1060-1065.

Cetinkaya G. \& Arat S. 2011. Cryopreservation of cartilage cell and tissue for biobanking. Cryobiology 63:292-297.

Costa U.M., Reischak D., Silva J. \& Ravazzolo A.P. 2005. Establishment and partial characterization of an ovine synovial membrane cell line obtained by transformation with Simian Virus $40 \mathrm{~T}$ antigen. J. Virol. Methods 128:72-78.
Desbiez A.L.J., Keuroghlian A., Beisiegel B.M., Medici E.P., Gatti A., Pontes A.R.M., Campos C.B., Tófoli C.F., Moraes Junior E.A., Azevedo F.C., Pinho G.M., Cordeiro J.L.P., Santos Junior T.S., Morais A.A., Mangini P.R., Flesher K., Rodrigues L.F. \& Almeida L.B. 2012. Avaliação do risco de extinção do cateto Pecari tajacu Linnaeus, 1758, no Brasil. Biod. Bras. 3:74-83.

Evecen M., Pabucçuoglu S., Alkan S. \& Ileri I.K. 2004. The effects of various BSA levels in different media on development in in vitro culture of mouse. Turk. J. Vet. Anim. Sci. 28:337-342.

Folch J., Cocero M.J., Chesné P., Alabart J.L., Domínguez V., Cognié Y., Roche A., Fernández-Arias A., Martí J.I., Sánchez P., Echegoyen E., Beckers J.F., Bonastre A.S. \& Vignon X. 2009. First birth of an animal from an extinct subspecies (Capra pyrenaica pyrenaica) by cloning. Theriogenology 71:1026-1034.

Gibbs S., Silva-Pinto A.N., Murli S., Huber M., Hols D. \& Ponec M. 2000. Epidermal growth fator and keratinocyte growth factor differentially regulate epidermal migration, growth and differentiation. Wound. Repair Regen. 8:192-203.

Goissis M.D., Caetano H.V.A., Marques M.G., Barros F.R.O., Feitosa W.B., Milazzotto M.P., Binelli N., Assumpção M.E.O.A. \& Visintin J.A. 2007. Effects of serum deprivation and cycloheximide on cell cycle of low and high passage porcine fetal fibroblasts. Reprod. Domest. Anim. 42:660-663.

Guan W.J., Ma Y.H., Ding H., Yu T.Y., Zhang H.Y. \& Liang H.Q. 2005. The establishment of fibroblast cell line and its biological characteristic research in small tail han sheep. Acta Veterinaria et Zootechnica Sinica 36:511-516.

Han Z.M., Chen D.Y., Li J.S., Sun Q.Y., Wang P.Y., Du J. \& Zhang H.M. 2003. Flow cytometric cell-cycle analysis of cultured fibroblasts from the giant panda, Ailuropoda melanoleuca L. Cell Biol. Int. 27:349-353.

Hosokawa M., Fijisawa H., Bing-Hua Z., Jujo H. \& Higuchi K. 1997. In vitro study of the mechanisms of senescence acceleration. Exp. Gerontol. 32:197-203.

Hudson L.G. \& McCawley L.J. 1998. Contributions of the epidermal growth factor receptor to keratinocyte motility. Microsc. Res. Techniq. 43:444-455.

Kan M. \& Yamane I. 1982. In vitro proliferation and lifespan of human diploid fibroblasts in serum-free BSA-containing medium. J. Cell Physiol. 112:155-162

Keuroghlian A., Desbiez R., Reyna-Hurtado M., Altrichter H., Beck A. \& Taber J.M.V. 2013. Tayassu pecari. In: IUCN Red List of Threatened Species. <http://dx.doi.org/10.2305/IUCN.UK.2013-1. RLTS.T41778A44051115.en> Accessed Nov. 7, 2015.

Keuroghlian A., Andrade Santos M.D.C. \& Eaton D.P. 2014. The effects of deforestation on white-lipped peccary (Tayassu pecari) home range in the southern Pantanal. Mammalia 79:491-497.

León-Quinto T., Simón M.A., Cadenas R., Jones J., Martínez-Hernández F., Moreno J.M., Vargas A., Martínez F. \& Soria B. 2009. Developing biological resource banks as a supporting tool for wildlife reproduction and conservation. Anim. Reprod. Sci. 112:347-361.

León-Quinto T., Simón M.A., Sánchez A., Martín F. \& Soria B. 2011. Cryobanking the genetic diversity in the critically endangered Iberian lynx (Lynx pardinus) from skin biopsies. Investigating the cryopreservation and culture ability of highly valuable explants and cells. Cryobiology 62:145-151.

León-Quinto T., Simón M.A., Cadenas R., Martínez A. \& Serna A. 2014. Different cryopreservation requirements in foetal versus adult skin cells from an endangered mammal, the Iberian lynx (Lynx pardinus). Cryobiology 68:227-233.

Li L.F., Yue H., Ma J., Guan W.J. \& Ma Y.H. 2009. Establishment and characterization of a fibroblast line from Simmental cattle. Cryobiology 59:63-68.

Li T. \& Lu L. 2005. Epidermal growth factor-induced proliferation requires down-regulation of pax6 in corneal epithelial cells. J. Biol. Chem. 280:12988-12995.

Lima G.L., Luz V.B., Alves A.M.C.V., Lunardi F.O., Souza A.L.P., Peixoto G.C.X., Rodrigues A.P.R., Oliveira M.F. \& Silva A.R. 2012. Vitrification of collared peccaries (Tayassu tajacu) ovarian tissue using various cryoprotectants. Preliminary results. Animal. Reprod. 9:957.

Liu C., Guo Y., Guan W., Ma Y., Zhang H.H. \& Tang X. 2008. Establishment and biological characteristics of Luxi cattle fibroblast bank. Tissue Cell 40:417-424. 
Liu C., Guo Y., Liu D., Guan W. \& Ma Y. 2010. Establishment and characterization of fibroblast cell line derived from Siberian Tiger (Panthera tigris altaica). Biopreserv. Biobank 8:99-105.

Liu C.Q., Guo Y., Guan W.J. \& Ma Y.H. 2011. Establishment and characterization of a fibroblast cell line derived from Mongolian sheep. Anim. Sci. J. 82:215-222.

Liu C., Guo Y., Lu T., Li X., Guan W. \& Ma Y. 2014. Establishment and genetic characteristics analysis of in vitro culture a fibroblast cell line derived from Wuzhishan miniature pig. Cryobiology 68:281-287.

Machado L.C., Oliveira V.C., Paraventi M.D., Cardoso R.N.R., Martins D.S. \& Ambrósio C.E. 2016 Maintenance of brazilian biodiversity by germplasm bank. Pesq. Vet. Bras. 36:62-66.

Magalhães R., Nugraha B., Pervaiz S., Yu H. \& Kuleshova L.L. 2012. Influence of cell culture configuration on the post-cryopreservation viability of primary rat hepatocytes. Biomaterials 33:829-836.

Mahesh Y., Rao B.S., Katari V.C., Komjeti S., Christo D., Lakshmikantan U. \& Shivaji S. 2012. Cell Cycle synchronization of Bison (Bos gaurus) fibroblasts derived from ear piece collected post-mortem. Reprod. Domest. Anim. 47:799-805.

Mosmann T.1983. Rapid colorimetric assay for cellular growth and survival: application to proliferation and cytotoxicity assays. J. Immunol. Methods. 16:55-63.

Na R.S., Zhao Q.J., Su X.H., Chen X.W., Guan W.J. \& Ma Y.H. 2010. Establishment and biological characteristics of Ujumqin sheep fibroblast line. Cytotechnology 62:43-52.

Pereira A.F., Feltrin C., Almeida K.C., Carneiro I.S., Avelar S.R.G., Alcântara Neto A.S., Sousa F.C., Melo C.H.S., Moura R.R., Teixeira D.I.A., Bertolini L.R., Freitas V.J.F. \& Bertolini M. 2013. Analysis of factors contributing to the efficiency of the in vitro production of transgenic goat embryos (Capra hircus) by handmade cloning (HMC). Small Rumin. Res. 109:163-172.

Piovezan U., Carneiro P.C.F., Maués M.S., Paiva S.R., Alencar J.R.M., Albuquerque N.I., Marques J.R.F., Pereira F.M., Pinheiro S.M. \& Resende E.K.
2012. Rede de recursos genéticos animais da Embrapa: espécies nativas com potencial econômico. Embrapa. http://www.alice.cnptia.embrapa. br/bitstream/doc/936036/1/10.pdf. Accessed Oct. 10, 2015.

Roth V. 2006. <http://www.doubling-time.com/compute.php> Accessed May 14, 2015.

Shi J., Zhou R., Luo L., Mai R., Zeng H., Xiaoyan H., Liu D., Zeng F., Cai G., Ji H., Tang F., Wang Q., Wu Z. \& Li Z. 2015. Influence of embryo handling and transfer method on pig cloning efficieny. Anim. Reprod. Sci. 154:121-127.

Silvestre M.A., Saeed A.M., Escribá M.J. \& García-Ximenez F. 2002. Vitrification and rapid freezing of rabbit fetal tissues and skin samples from rabbits and pigs. Theriogenology 58:69-76.

Silvestre M.A., Saeed A.M., Cervera R.P., Escribá M.J. \& García-Ximénez F. 2003. Rabbit and pig ear skin sample cryobanking: effects pf storage time and temperature of the whole ear extirpated immediately after death. Theriogenology 59:1469-1477.

Singh M. \& Xiaoling M.A. 2014. In vitro culture of fibroblast-like cells from sheep ear skin stored at $25-26^{\circ} \mathrm{C}$ for 10 days after animal seath. Int. J. Biol. 6:96-102.

Singh M., Ma X., Amoah E. \& Kannan G. 2011. In vitro culture of fibroblast-like cells from postmortem skin of Katahdin sheep stored at $4^{\circ} \mathrm{C}$ for different time intervals. In Vitro Cell Dev.-An. 47:290-293.

Souza A.L.P., Lima G.L., Peixoto G.C.X., Silva A.M., Oliveira M.F. \& Silva A.R. 2016. Use of Aloe vera-based extender for chilling and freezing collared peccary (Pecari tajacu) semen. Theriogenology 85:1432-1438.

Strober W. 2001. Trypan blue exclusion test of cell viability. Curr. Protoc. Immunol. Appendix 3: Appendix 3B.

Urio M., Duarte C.R.A., Fleith R.C., Munhoz M.L., Zago F.C., Forell F., Mezzalira A., Bertolini M. \& Costa U.M. 2011. Cryopreservation of somatic cells in $0.5 \mathrm{~mL}$ or $0.25 \mathrm{~mL}$ straws and propylene glycol or ethylene glycol. Acta Scient. Vet. 39:S454.

Wu H.M., Guan W.J., Li H. \& Ma Y.H. 2008. Establishment and characteristics of white ear lobe chicken embryo fibroblast line and expression of six fluorescent proteins in the cells. Cell Biol. Int. 32:1478-1485. 